第72回日本内科学会講演会（1975年）

\title{
シンポジウム 慢性呼吸不全
}

（1）慢性呼吸不全の病態之その背景

慶応義塾大学医学部内科学教室

横山哲 朗

SYMPOSIUM ON CHRONIC RESPIRATORY FAILURE

(1) CHRONIC RESPIRATORY DISTRESS-CLINICAL SIGNIFICANCE

OF ARTERIAL BLOOD GAS ABNORMALITIES

Tetsuro Yoxoyama, M.D.

Department of Medicine, School of Medicine, Keio University, Tokyo

\section{1. 緒論，慢性呼吸不全の定義}

呼吸不全と表現される病的状態を讋断する基準 に関し，現時点において普辺的な条件がきめら てはいない，著者は“原因の如何を問わず動脈血 ガス(とくに $\mathrm{O}_{2}$ 执よび $\left.\mathrm{CO}_{2}\right)$ が異常な值を示し，そ れがために生体が正常な機能を営み得なくなつた 状熊”字呼吸不全と定義することと乙，その状態 が相当長期間，少なくとも 1 カ月以上にわたつて 持続するとき，これを慢性呼吸不全と呼ぶことと した．本報告に执いては，この考え方にもとづい て動脈血ガス分析の成績を中心に臨床例にみられ た呼吸不全症例の病態をその背景となつた疾患の 検討を含めて述べた。なお検討の対象とした症例 は無作為的に兄らばれたものでも，あるいは予め 作製せられた奏験計画によつて抽出されたるので もなく，担当医師が検査を必要と判断して兄らえ た゚症例であるが故にこの成績のみから全般の疫学 的動向の詳細を把握することは期待できないが， 今日の臨休に和ける問題点を明らかになし得るる のと考觉た，また解析をルチーンの臨床検查成績 に限定したのb，交ず基本的問題点を的確に理解 することが必要と考党たからである。

\section{2. 対象ならひに方法}

臨床検查の目的で動脈血検查を実施した合計 3638件のうち，同一症例に繰返して実施した検査 成續はこれを除外し，1症例に 1 回のみの成績を とりあげた，室内気呼吸時に動脈血採血を行なう ことができた2983症例の成績を主として述べる。 このららルチーンのスパイロメトリーを動脈血検 查と同一の日に行ない得たものは1116例であつ た、スパイロメトリーを平行的に実施し得なかつ た症例の中には，スパイロメトリーに耐光られな い病状のるのが少なからず含まれていた。な踆 素療法中に動脈血検查を行なわねばならなかつた 146例につき得られた成績について子後述する。

刘象症例の病名は一部には生検, 手術るるいは 剖検により確認されたものもあつたが，原則とし てX線所見および肺機能検査所見を含めた臨床知 見にもとついてきめられた。盿線維化については 原因を知り得たものについてはこれを別個に分類 した。 “細気管支炎症候群bronchiolitis syndrome” としたものは末梢肺領域に局在する病変により 自他覚的臨床症状を呈する一群の肺疾患で, ここ にとりあげた他の疾患から除外されたるのをい 5 . 
分析に供した動脈血試料は，背卧位にて恒常状 態を保たせた患者の时動脈よりへパリン溶液で密 封したガラス製10mlルアーロック注射器に採取 し，予め較正をすませた I Lメーター 113型を用 W，可及的速やかに $\mathrm{O}_{2}$ 分圧, $\mathrm{CO}_{2}$ 分圧, $\mathrm{pH}$ 測定 を行なつた。採血より分析までの経過時間にもと ついて湘定值の補正を行なつた。

肺胞気・動脈血 $\mathrm{O}_{2}$ 分王較差 $\left(\mathrm{AaDo}_{2}\right)$ を算出す るために肺胞気 $\mathrm{O}_{2}$ 分正をガス交換率を 0.83 と仮 定して肺胞式を用いて求めた。

\section{3. 成 績}

1）動脈血 $\mathrm{O}_{2}$ 分王：

険討の対象とした2983例の 動脈血 $\mathrm{O}_{2}$ 分圧の平 均値ならびにその標準偏差は75.0土27.1 T O R R であり，そのうち1484例（49.7\%）では動脈血 $\mathrm{O}_{2}$ 分圧が75 T O R R以下，1110例（37.2\%）では70 T OR R以下，また 243例 (8.2\%)ではそれが50 TOR R以下であつた（表 1). 表 1 《は対象症例 の疾患別内訳を症例数，動脈血 $\mathrm{O}_{2}$ 分圧平均值なら

Table 1. Classified numbers of cases, mean and standard deviation for the arterial $\mathrm{Po}_{2}$ and prevalence of depressed arterial $\mathrm{Po}_{2}$. Figures in the parenthesis indicate prevalence. *LOC FIB : localized fibrotic change of the the lungs. **DIF FIB : diffuse fibrotic change of the lungs. ***IAT FIB : pulmonary fibrotic change caused by BLEOMYCIN treatment or by irradiation therapy. ****OCC FIB : occupational pneumoconiosis. 'SYST FIB : pulmonary fibrotic change accompanied by the systemic diseases.

\begin{tabular}{|c|c|c|c|c|c|c|c|c|c|}
\hline \multirow[t]{2}{*}{ CLIMICAL DIAG. } & \multirow{2}{*}{$\begin{array}{l}\text { No.OF } \\
\text { CASES }\end{array}$} & \multirow[t]{2}{*}{ MEAN } & \multirow[t]{2}{*}{ S.D. } & \multicolumn{6}{|c|}{ ARTERIAL ' $P_{0}$} \\
\hline & & & & below & * 75 TORR & below & 70 TORR & below & $50 \mathrm{TORR}$ \\
\hline HEALTHY & 159 & {$\left[\begin{array}{c}\text { TORR } \\
96,0\end{array}\right]$} & $\begin{array}{c}\text { TORR } \\
6.2\end{array}$ & 0 & $\%$ & & $\%$ & & $\%$ \\
\hline ASTHMA & 292 & 71.0 & 24.8 & 175 & $(59.9)$ & 130 & $(44,5)$ & & $(7.5)$ \\
\hline EMPHYSEMA & 240 & 69.1 & 14.1 & 170 & $(70,8)$ & 129 & $(53.8)$ & 24 & $\{10.0\}$ \\
\hline BRONCHITIS & 237 & 83.5 & 23.1 & 54 & $(22.8)$ & 24 & $(10.1)$ & 0 & \\
\hline $\begin{array}{l}\text { "BRONCHIOLI- } \\
\text { TIS SYNDROME" }\end{array}$ & 357 & 78.2 & 10.6 & 128 & $\{33,1\}$ & 74 & $(20.7)$ & 2 & $(0,6)$ \\
\hline PNEUMONITIS & $\$ 0$ & 62.9 & 15.0 & 72 & $" 80,0\}$ & 62 & $(68.9)$ & 16 & $(7,8)$ \\
\hline LOC FIB* & 13 & 69,4 & 10.3 & 10 & $(76.9)$ & 6 & $(46.2)$ & $i$ & $(15,4)$ \\
\hline DIF F18** & 271 & 68.5 & 45.6 & 193 & (71.2) & 158 & $(58.3)$ & 44 & (16.2) \\
\hline IAT $F 1 B^{* * * *}$ & 62 & 72.3 & 13.9 & 34 & $(54.8)$ & 25 & $(40,3)$ & 4 & $(6,5)$ \\
\hline OCC $F 1 B^{* * * * *}$ & 5 & 74.8 & 10.4 & 3 & $(60.0)$ & 2 & $(40.0)$ & 0 & \\
\hline SYST FIB" & 82 & 68.9 & 19.2 & 48 & (58.5) & 38 & (46.3) & 18 & $(22.0)$ \\
\hline BRONCHIECTASIS & 114 & 69.6 & 14.8 & 77 & $(67.5)$ & 54 & $(47.4)$ & 11 & $(9.7)$ \\
\hline TUBERCULOSIS & 139 & 64.9 & 17.5 & 95 & (68.8) & 73 & $(52.9)$ & 27 & $(19,6)$ \\
\hline LUNC CANCER & 210 & 67.0 & 17.3 & 158 & $(75.2)$ & 129 & (61.9) & 28 & (13.3) \\
\hline SARCOIDOSIS & $\$$ & 78.7 & 27,1 & 2 & $\{40,0\}$ & 2 & $(40,0)$ & 0 & \\
\hline $\begin{array}{l}\text { THORACIC } \\
\text { DEFORMITY }\end{array}$ & 30 & $\infty 0.0$ & 20.5 & 20 & $\{66.7\}$ & 19 & (69.3) & 12 & $(40,0)$ \\
\hline PULM EMBOLISM & 20 & 57,8 & 25.7 & 17 & $(85.0)$ & 13 & $(65.0)$ & 4 & $(20,0)$ \\
\hline CARDIAC DIS. & 179 & 74,2 & 13.2 & 97 & $(76.3)$ & 72 & $(19.5)$ & 10 & (2.7) \\
\hline OTHERS & $4 B 1$ & 83.1 & 46.8 & 144 & $(29.3)$ & 100 & $(20,8)$ & 19 & $(4.0)$ \\
\hline TOTAL & 2993 & 75.0 & 27.1 & 1484 & $4(19.7)$ & mo & $(37.2)$ & 243 & $(8.1)$ \\
\hline
\end{tabular}

びに標準偏差，動脈血 $\mathrm{O}_{2}$ 分王が75 T O R R以下， 70 T O R R以下，50 T O R R以下であつた症例数 ならびにその対象症例数に対する百分比を発現率 として示した（表1).

健常者 159例中空気呼吸時にその動脈血 $\mathrm{O}_{2}$ 分圧 が75 T OR R以下であつたものは 1 例もなから た. 疾患例で動脈血 $\mathrm{O}_{2}$ 分圧が75 T O R R以下を示 したもののらち著者が確認し得たもの全例で無視 できない程度の自・他覚的異常所見があつた．動 脈血 $\mathrm{O}_{2}$ 分圧が 75 T O R R 以下であつた症例と 70 TORR以下であつたものとの間には症例数にし て 374例, 発現率にして12.5\%の差があつた。

疾患別にみると動脈血 $\mathrm{O}_{2}$ 分圧が75 T O R R以 下のものの発現率は肺塞栓症, 各種肺缄炎, 局在 性扝よびびまん性肺線維化, 肺気腫, 肺がんなら びに各種心疾患において70\%をこ兄ていた．動脈 血 $\mathrm{O}_{2}$ 分圧が 50 T O R R 以下のものの発現率は肺 塞栓症,びまえ性肺線維化，系統疾患に合併した

Table 2. Classified numbers of cases with arterial oxygen tension below 75 torr in terms of arterial $\mathrm{CO}_{2}$ tension. Figures in the parenthesis indicate the prevalence. *LOC FIB : localized fibrotic change of the lungs. **DIF FIB : diffuse fibrotic change of the lungs. ***IAT FIB : pulmonary fibrotic change caused by BLEOMYCIN treatment or by irradiation therapy. ****OCC FIB : occupational pneumoconiosis. 'SYST FIB : pulmonary fibrotic change accompanied by the systemic diseases.

\begin{tabular}{|c|c|c|c|c|c|c|c|}
\hline \multirow[t]{2}{*}{ CLINICAL DIAGNOSIS } & \multirow{2}{*}{$\begin{array}{l}\text { NO.OF } \\
\text { CASES }\end{array}$} & \multicolumn{6}{|c|}{ ARTERIAL $\mathrm{PCO}_{2}$} \\
\hline & & over & 46 TORR & $36-4$ & 5 TORR & below & 35 TORR \\
\hline & & & $\%$ & & $\%$ & & $\%$ \\
\hline HEALTHY & 0 & 0 & & 0 & & 0 & \\
\hline ASTHMA & 175 & 52 & $(29.7)$ & 94 & $(53,7)$ & 29 & $(16.6)$ \\
\hline EMPHYSEMA & 170 & 56 & (32.9) & 96 & $(56.5)$ & 18 & $(10,6)$ \\
\hline BRONCHITIS & 54 & 11 & (20.4) & 28 & $(70,4)$ & 5 & $(9,3)$ \\
\hline $\begin{array}{l}\text { "BRONCHOLITIS } \\
\text { SYNDROME" }\end{array}$ & 118 & 8 & $(6.8)$ & 93 & $(78.8)$ & 17 & $(14.4)$ \\
\hline PNEUMONITIS & 72 & 14 & $(19.4)$ & 31 & $(43.1)$ & 27 & $(37.5)$ \\
\hline LOC FIB* & 10 & I & $(10,0)$ & 7 & $(70,0)$ & 2 & $(20.0)$ \\
\hline DIF FIB** & 193 & 30 & (15.5) & 101 & $(52.3)$ & 62 & $(32.1)$ \\
\hline IAT FIB *** & 34 & 0 & & 25 & $(73.5)$ & 9 & $(26.5)$ \\
\hline OCC FIB ***** & 3 & 0 & & 1 & $(33.3)$ & 2 & $(67.7)$ \\
\hline SYST FIB & 48 & 9 & (18.8) & 13 & $(27.1)$ & 26 & $(54.2)$ \\
\hline BRONCHIECTASIS & 77 & 18 & $(23.4)$ & 55 & $(71.4)$ & 4 & $(5.2)$ \\
\hline TUBERCULOSIS & 95 & 57 & $(60.0)$ & 27 & $(28.4)$ & 11 & (11.6) \\
\hline LUNC CANCER & 158 & 22 & (13.9) & 82 & $(51.9)$ & 54 & $(34.2)$ \\
\hline SARCOIDOSIS & 2 & 0 & & 0 & & 2 & $(100.0)$ \\
\hline $\begin{array}{l}\text { THORACIC } \\
\text { DEFORMITY }\end{array}$ & 20 & 18 & $(90.0)$ & 1 & $(5.0)$ & 1 & $(5,0)$ \\
\hline PULM EMBOLISM & 17 & 2 & (11.8) & 4 & $(23.5)$ & il & $(64.7)$ \\
\hline CARDIAC DIS. & 97 & 5 & $(5,2)$ & 40 & $(41,2)$ & 52 & $(53.6)$ \\
\hline OTHERS & 141 & 13 & $(9.2)$ & 58 & $(41.1)$ & 70 & $(49.6)$ \\
\hline TOTAL & 1484 & 316 & $(21,3)$ & 766 & $(51.6)$ & 402 & $(27,1)$ \\
\hline
\end{tabular}


肺線維化, 肺結核ならびに胸かく变形例において 高値を示しこれと前述した75 T O R R以下の発 現率とは必らずしる平行的な関係になく, 疾患に よる傾向の若干の差異の存在を示していた。肺・ 胸かく系に病変を認めないその他の疾患において も481例中 141 症 $(29.3 \%)$ 飞動脈血 $\mathrm{O}_{2}$ 分王か 75 T OR R以下のものが見られた。

2）動脈血 $\mathrm{CO}_{2}$ 分王 :

2983症例の動脈血 $\mathrm{CO}_{2}$ 分圧の平均値ならびに標 準偏差は 40.42士 24.72 T OR Rであつた。この 中に含まれる健常例 159例についての $\mathrm{CO}_{2}$ 分正平 均值ならびに標準偏差は 39.20土4.15 T O R Rで あつた。疾患別にみて動脈血 $\mathrm{CO}_{2}$ 分圧平均值か 45.0T ORRをこ学ていたものは気管支拡張症 $45.22 \pm 50.13$ T O R R，肺結核症 49.57士15.00 T ORR，胸方く変形 $62.15 \pm 21.75$ T OR Rで あつた。一方 $\mathrm{CO}_{2}$ 分王平均值が $35.0 \mathrm{~T} \mathrm{OR} \mathrm{R以下}$

Table 3. Mean and standard deviation for the alveolar-arterial oxygen tension difference obtained on 1484 cases with respiratory distress. *LOC FIB : localized fibrotic change of the lungs. **DIF FIB : diffuse fibrotic change of the lungs. ***IAT FIB : pulmonary fibrotic change caused by BLEO MYCIN treatment or by irradiation therapy. **** OCC FIB : occupational pneumoconiosis. 'SYST FIB : pulmonary fibrotic change accompanied by the systemic diseases.

\begin{tabular}{l|c|c|c}
\hline \multicolumn{1}{c|}{ CLINICAL DIAG. } & NO. OF CASES & MEAN & S.D. \\
\hline & & TORR & TORR \\
HEALTHY & 175 & 37.14 & $\ldots \ldots$ \\
ASTHMA & 170 & 32.42 & 19.14 \\
EMPHYSEMA & 54 & 32.37 & 6.50 \\
BRONCHITIS & 118 & 35.55 & 8.37 \\
"BRONCHIOLITIS & 72 & 46.21 & 15.65 \\
SYNDROME" & 10 & 37.17 & 8.84 \\
PNEUMONITIS & 193 & 40.83 & 38.75 \\
LOC FIB* & 34 & 41.69 & 13.40 \\
DIF FIB** & 3 & 40.70 & 7.29 \\
IAT FIB*** & 48 & 38.81 & 69.91 \\
OCC FIB**** & 77 & 37.17 & 10.92 \\
SYST FIB* & 95 & 29.12 & 15.50 \\
BRONCHIECTASIS & 158 & 44.30 & 14.67 \\
TUBERCULOSIS & 2 & 53.11 & 0.03 \\
LUNG CANCER & 20 & 17.63 & 21.06 \\
SARCOIDOSIS & 17 & 59.62 & 44.45 \\
THORACIC DEFORMITY & 97 & 44.05 & 12.27 \\
PULM. EMBOLISM & 141 & & \\
CARDIAC DIS. & 1484 & 38.10 & 32.01 \\
OTHERS & & & \\
TOTAL & & & \\
\hline
\end{tabular}

であつた疾患は肺塞栓症 $30.92 \pm 16.51 \mathrm{TOR}$ R，サルコイドーシス $33.60 \pm 3.14$ T O R Rであ つた.

動脈血 $\mathrm{O}_{2}$ 分王が 75 T O R R 以下の 呼吸不全例 1484例について動脈血 $\mathrm{CO}_{2}$ 分圧をみた（表 2). 動 脈血 $\mathrm{CO}_{2}$ 分仕が36ないL45 T O R R 範囲内にあ つたものは 766例(51.6\%)であり， $\mathrm{CO}_{2}$ 分圧が46 T OR R以上あつたもの 316例 (21.3\%)，それが 35 T O R R以下であつたもの 402例 $(27.1 \%$ ) が みられた。疾患別にみると喘息, 肺気腫, 気管支 炎, 気管支拡張症, 肺結核症, 胸かく変形例では 動脈血 $\mathrm{CO}_{2}$ 分圧が 異常な高值を呈したものが35 T OR R以下の異常な低值を呈したものより多か つた。しかるに細気管支炎症候群, 肺臓炎, 各種 の肺線維化, 肺がん，サルコイドーシス, 肺塞栓 症，心疾患などに和いては $\mathrm{CO}_{2}$ 分王が異常な低值 を示した症例が高值を示したものより多く，こと

Table 4. Mean and standard deviation for the alveolar-arterial oxygen tensicn difference obtained on 85 cases of respiratory distress with normal spirometry. *LOC FIB : localized fibrotic change of the lung. **DIF FIB : diffuse fibrotic change of the lungs. ***IAT FIB : pulmonary fibrotic change caused by BLEOMYCIN treatment or by irradiation therapy. ****OCC FIB : occupational pneumoconiosis. 'SYST FIB : pulmonary fibrotic change accomanied by the systemic diseases.

\begin{tabular}{l|c|c|c}
\hline \multicolumn{1}{c|}{ CLINICAL DIAG. } & $\begin{array}{c}\text { NO. OF } \\
\text { CASES }\end{array}$ & MEAN & S.D. \\
\hline & & TORR & TORR \\
HEALTHY & 0 & $\ldots \ldots$ & $\ldots \ldots$ \\
ASTHMA & 10 & 37.98 & 12.19 \\
EMPHYSEMA. & 1 & 40.10 & 0.00 \\
BRONCHITIS & 15 & 32.65 & 4.56 \\
"BRONCHIOLITIS & 31 & 32.39 & 5.36 \\
SYNDROME" & 2 & 46.03 & 26.21 \\
PNEUMONITIS & 1 & 32.92 & 0.00 \\
LOC FIB* & 8 & 32.18 & 4.59 \\
DIF FIB** & 1 & 30.01 & 0.00 \\
IAT FIB*** & 1 & 43.71 & 0.00 \\
OCC FIB**** & 1 & 32.60 & 0.00 \\
SYST FIB* & 2 & 31.84 & 9.05 \\
BRONCHIECTASIS & 1 & 30.63 & 0.00 \\
TUBERCULOSIS & 2 & 21.42 & 10.88 \\
LUNG CANCER & 0 & $\ldots \ldots$ & $\ldots .$. \\
SARCOIDOSIS & 0 & $\ldots . .$. & $\ldots .$. \\
THORACIC DEFORMITY & 2 & 37.09 & 4.57 \\
PULM. EMBOLISM & 4 & 36.86 & 6.18 \\
CARDIAC DIS. & 3 & & \\
OTHERS & 85 & 33.70 & $\mathbf{8 . 5 0}$ \\
TOTAL & & & \\
\hline
\end{tabular}


に職業じん肺, 系統疾患に合併した肺線維化，サ ルコイドーシス, 肺塞栓症, 心疾患のように当該 疾患例の $50 \%$ 以上が $\mathrm{CO}_{2}$ 分圧 35 T O R R以下を呈 することがわからた。

3）肺胞気 - 動脈血 $\mathrm{O}_{2}$ 分圧較差 $\left(\mathrm{AaDo}_{2}\right)$ : 2983症例 $の \mathrm{AaDo}_{2}$ の平均值ならびに標準偏差は

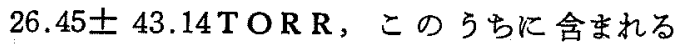
159例の健常例の $\mathrm{AaDo}_{2}$ のそれは6.86士6.04 T O R Rであつた。

1484例の動脈血 $\mathrm{O}_{2}$ 分圧が75 T O R R 以下の呼 吸不全例の $\mathrm{AaDo}_{2}$ を検討した（表 3). $\mathrm{AaDo}_{2}$ の平

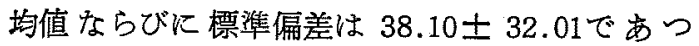
た. 表 3 にみられると打り疾患別にみた $\mathrm{AaDo}_{2}$ の 平均值は胸かく変形例を除いて，いす゚れも25 T O R Rを上迴つていた．とくにAaDo のは肺臓炎,びまん性肺線維化, 治療に伴な5肺 線維化，職業じえ肺，肺がえ，サルコイドーシ ス, 肺塞栓症, 心蔵疾患例であつた。 $\mathrm{AaDo}_{2}$ は必 らずしも正規分布するわけではないので測定值の
バラッキの度合の半定量的指標にしかすぎないが 標準偏差をみるとその大きさには著しい疾患別差 異があり，その大小は，平均值の大小とは必らず しも平行的な関俰にはなかつた（表 3 ）.

呼吸不全例のうちより，スパイロメトリーで\% 肺活量拈よび 1 秒率が正常範囲内にあつたもの が85症例あつた。 この 85症例のみについて求め た $\mathrm{AaDo}_{2}$ の平均值ならびに標準偏差を表 4 にまと めた（表 4). 全般について求めた $\mathrm{AaDo}_{2}$ の平均値 なびらに標準偏差は133.70土8.50TORRでその平 均値は呼吸不全症例全体について求めた值 (38.10 TOR R，表 3）より僅かながら小さかつた.

2983 症例中動脈血 $\mathrm{O}_{2}$ 分代が $90 \mathrm{~T}$ O R R 以上あ り，な特かつ $\mathrm{AaDo}_{2}$ が20 T O R R以上あつたもの は31例, $\mathrm{AaDo}_{2}$ が $25 \mathrm{~T}$ OR R以上あつたものは 17 例みられた。また動脈血 $\mathrm{O}_{2}$ 分圧が75T OR R以下 であるにもかかわらず $\mathrm{AaDo}_{2} か ゙ 10 \mathrm{~T}$ OR R以下の 症例が44例みられた。

4）スパイロメトリーと動脈血ガス：

Table 5. Arterial $\mathrm{O}_{2}$ tension, $\mathrm{CO}_{2}$ tension and alveolar-arterial $\mathrm{O}_{3}$ tension difference in terms of the types of ventilatory capacity. Figures without parenthesis indicate numbers of subjects and figures in the parenthesis represent percent prevalence. *INDEX : percent $\left(\mathrm{FEV}_{1} /\right.$ predicted VC), **NO. RMAL : normal spirometry, ***RESTR : restrictive ventilatory impairment, ****COMBINED : combined ventilatory impairment, *****OBSTRUCT : obstructive ventilatory impairment.

\begin{tabular}{|c|c|c|c|c|c|c|c|}
\hline \multirow{2}{*}{$\begin{array}{l}\text { VENTILATORY } \\
\text { CAPACITY }\end{array}$} & \multirow{2}{*}{$\begin{array}{l}\text { NO:OF } \\
\text { CASES }\end{array}$} & \multicolumn{6}{|c|}{ ARTERIAL PO2 } \\
\hline & & \multicolumn{2}{|c|}{ below 75} & \multicolumn{2}{|c|}{ below 70} & \multicolumn{2}{|c|}{ below 50} \\
\hline 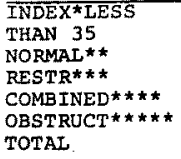 & $\begin{array}{l}330 \\
426 \\
295 \\
250 \\
145 \\
1116\end{array}$ & $\begin{array}{l}192 \\
85 \\
122 \\
157 \\
75 \\
439\end{array}$ & $\begin{array}{l}(58.2) \\
(20.0) \\
(41.4) \\
(62.8) \\
(51.7) \\
(39.3)\end{array}$ & $\begin{array}{l}130 \\
34 \\
84 \\
106 \\
49 \\
273\end{array}$ & $\begin{array}{l}(39.4) \\
(8.0) \\
(28.5) \\
(42.4) \\
(33.8) \\
(24.5)\end{array}$ & $\begin{array}{l}14 \\
2 \\
13 \\
9 \\
3 \\
27\end{array}$ & $\begin{array}{l}(4.2) \\
(0.5) \\
(4.4) \\
(3.6) \\
(2.1) \\
(2.4)\end{array}$ \\
\hline \multicolumn{8}{|l|}{ ARTERIAL PCO2 } \\
\hline \multirow{2}{*}{$\begin{array}{l}\text { VENTILATORY } \\
\text { CAPACITY }\end{array}$} & \multirow{2}{*}{$\begin{array}{l}\text { No.OF } \\
\text { CASES }\end{array}$} & \multicolumn{6}{|c|}{ ARTERIAL PCO2 } \\
\hline & & belo & 75 & belc & 70 & belc & 50 \\
\hline $\begin{array}{l}\text { INDEX }{ }^{\star} \text { LESS } \\
\text { THAN } 35 \\
\text { NORMAL }{ }^{\star *} \\
\text { RESTR*** } \\
\text { COMBINED } * \star \star \star \\
\text { OBSTRUCT } * \star \star \star * \\
\text { TOTAL }\end{array}$ & $\begin{array}{l}330 \\
426 \\
295 \\
250 \\
145 \\
1116\end{array}$ & $\begin{array}{l}79 \\
21 \\
20 \\
62 \\
15 \\
118\end{array}$ & $\begin{array}{l}(23.9) \\
(4.9) \\
(6.8) \\
(24.8) \\
(10.3) \\
(10.6)\end{array}$ & $\begin{array}{l}207 \\
347 \\
209 \\
162 \\
106 \\
824\end{array}$ & $\begin{array}{l}(62.7) \\
(81.5) \\
(70.8) \\
(64.8) \\
(73.1) \\
(73.8)\end{array}$ & $\begin{array}{l}44 \\
58 \\
66 \\
26 \\
24 \\
174\end{array}$ & $\begin{array}{l}(13.3) \\
(13.6) \\
(22.4) \\
(10.4) \\
(16.6) \\
(15.6)\end{array}$ \\
\hline
\end{tabular}

ALVEOLAR-ARTERIAL O2 TENSION DIFFERENCE

\begin{tabular}{|c|c|c|c|c|c|c|c|c|c|c|c|}
\hline \multirow{2}{*}{$\begin{array}{l}\text { VENTILATORY } \\
\text { CAPACITY }\end{array}$} & \multirow{2}{*}{$\begin{array}{l}\text { NO. OF } \\
\text { CASES }\end{array}$} & \multicolumn{6}{|c|}{$\mathrm{AaDO} 2$} & \multirow{2}{*}{\multicolumn{2}{|c|}{$21-30$}} & \multirow{2}{*}{\multicolumn{2}{|c|}{ over 31}} \\
\hline & & belc & 710 & $11-$ & & $16-2$ & & & & & \\
\hline 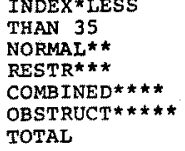 & $\begin{array}{l}330 \\
426 \\
295 \\
250 \\
145 \\
1116\end{array}$ & $\begin{array}{l}36 \\
98 \\
37 \\
25 \\
15 \\
175\end{array}$ & $\begin{array}{l}(10.9) \\
(23.0) \\
(12.5) \\
(10.0) \\
(10.3) \\
(15.7)\end{array}$ & $\begin{array}{l}22 \\
68 \\
21 \\
17 \\
14 \\
120\end{array}$ & $\begin{array}{l}(6.7) \\
(16.0) \\
(7.1) \\
(5.8) \\
(9.7) \\
(10.8)\end{array}$ & $\begin{array}{l}28 \\
70 \\
32 \\
17 \\
18 \\
137\end{array}$ & $\begin{array}{l}(8.5) \\
(16.4) \\
(10.8) \\
(6.8) \\
(12.4) \\
(12.3)\end{array}$ & $\begin{array}{l}114 \\
123 \\
96 \\
92 \\
44 \\
355\end{array}$ & $\begin{array}{l}(34.5) \\
(28.9) \\
(32.5) \\
(36.8) \\
(30.3) \\
(31.8)\end{array}$ & $\begin{array}{l}130 \\
67 \\
109 \\
99 \\
54 \\
329\end{array}$ & $\begin{array}{l}(39.4) \\
(19.7) \\
(36.9) \\
(39.6) \\
(37.2) \\
(29.5)\end{array}$ \\
\hline
\end{tabular}


スパイロメトリーと動脈血ガス分析とを同じ日 に実施し得た1116症例について, 換気能力と動脈 血との関係を調べた（表 5 ）.換気能力は 1 秒量の 予測胡活量に対する百分比 (以下指数 index と略 記）％肺活量と 1 秒率につき区分した正常換気 機能，拘束性，混合性おょび閉塞性各換気障害に つき検討した，動脈血 $\mathrm{O}_{2}$ 分圧が75 T O R R以下の 症例は439例（39.3\%)，70 T OR R以下の症例は 273例 $(24.5 \%) ， 50$ T OR R 以下の症例は 27 例 $(2.4 \%)$ あつた。

指数35以下の症例 330 例についてみると， $\mathrm{O}_{2}$ 分 圧75 T O R R以下のむのは192例 $(58.2 \%), 70 \mathrm{~T}$ O R R以下のものは130例 (39.4\%)，50 T OR R 以下のものは14例 (4.2\%)であつた（表 5 ).

換気能力の型と動脈血ガスとの関係を $\mathrm{O}_{2}$ 分圧 75 T OR R以下の症例についてみると, 正常換気 能力ではその $20.0 \%$ がこれ該当するに過ざなか つたが拘束性障害例では， $41.4 \%$, 閉塞性障害例 では $51.7 \%$, 混合性障害例で最も高率に62.8\%が これに該当していた。動脈血 $\mathrm{O}_{2}$ 分圧が50 T O R R 以下の症例は合計27例にすぎず，詳細な比較を行 なうには十分でなからたが，拘束性障害例で最も 多く，そつ百分比についてみても拘束性障害例で 最も高値がみられた。

疾患例にもこれを検討したが，ここではその代 表として肺気腫とびまん性線維化例を対比させて 述べる. 脑気腫症例 124例中, 指数が35以下であ

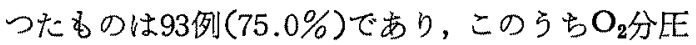
が75 T O R R以下のものは54例 (58.1\%) であっ た。びまん性肺線維化例についてみると，109例 中指数が35以下のものは53例 $(48.6 \%)$ にすきなか つたが，そのうちにO 2 分圧が75 T O R R以下のる のが33例 $(62.3 \%)$ 又られ, さらに $\mathrm{O}_{2}$ 分圧が50 T O R R以下のものが肺気腫例より多かつた。この ことは肺気腫例ではびまえ性肺線維化例に較べて 換気障害が著しく, 肺線維化例では換気障害に比 較して血液ガス異常が著明であつた事実を示して いる. 肺線維化例で性束性障害がとくに著しく 肺気腫例で 1 秒率の低下が比較的に著明であつた ことはあらためて申述べるまでもない。

動脈血 $\mathrm{CO}_{2}$ 分圧についてみると，ここで対象
となる 1116症例の内訳を表 5 に示した。824例 $(73.8 \%)$ は $\mathrm{CO}_{2}$ 分圧が36ないし45 T OR Rの正常 範囲内にあつた． $\mathrm{CO}_{2}$ 分圧が45 T OR Rをこえた ものは，118例 (10.6\%) あつたのに対して， $\mathrm{CO}_{2}$ 分圧が35 T O R R以下であつた症例は，174 例(15.6\%)みられた。換気能力の型別にみると混 合性换気障害例を除いて他はすべて $\mathrm{CO}_{2}$ 分圧が35 T O R R以下の症例数が 45 T O R R以上のむのよ り多かつた．この傾向は拘束性障害例にとくに著 しく認められた。しかしながら指数 35 以下の症例 にかんしては $\mathrm{CO}_{2}$ 分圧が45 T OR Rをこえる症例 が， $\mathrm{CO}_{2}$ 分圧35 T OR R以下のるのりり多く認め られた。

動脈血 $\mathrm{O}_{2}$ 分圧75 T O R R以下を呈した呼吸不 全例の $\mathrm{CO}_{2}$ 分圧をみると, それが正常範囲内にあ つたものの百分比には著しい差異がなかつたが， $\mathrm{CO}_{2}$ 分生が45 T OR Rをこえたものの百分比と35 TOR R以下であつたものの百分比との関係が， 全体の症例に猢るとさ逆転していた（表 6 ）。こ れを換気能力別にみると正常，拘束性あるいは閉 塞性障害例では，両者の関係は全体についてみた 場合に較べて大きな差はなく，混合性障害例に拈 いて $\mathrm{CO}_{2}$ 蓄積を呈する症例が比較的に増加してい たのがわかつた。

1116症例について $\mathrm{AaDo}_{2}$ をるとそれは広範囲 に分布しており，20TORRをこえたものが 61.3 \%にみられた。拘束性障害，混合性障害および閉 塞性障害を呈した症例に捺いて $\mathrm{AaDo}_{2}$ の分布のパ ターンに著明な差異を見出し得なかつた（表 5 ）。 換気能力が正常範囲内にめつた 426例についてみ ると， $\mathrm{AaDo}_{2}$ が10 T O R R以下であつたものは96 例 $(23.0 \%)$ に過ぎず，20 T OR Rをこ光たもの が190例（48.6\%）るみられた（表 5 ). 動脈血 $\mathrm{O}_{2}$ 分王が，75T OR R以下の呼吸不全例中にも换気 能力が正常範囲内にあつたものが85例 みられた (表 6 )。この中には $\mathrm{AaDo}_{2}$ が20 T OR Rをこえる 症例が83例(97.7\%)含まれていた．何らかの換気 障害を呈した呼吸不全例に叔いても，その障害の 型による差異は明らかでなく， $\mathrm{AaDo}_{2}$ の分布は表 5 に示した1116例の場合に較べて，全般的にそれ が相対的増加の傾向を呈した。 
Table 6. Arterial $\mathrm{O}_{2}$ tension, $\mathrm{CO}_{2}$ tension and alveolar-arterial $\mathrm{O}_{2}$ tension difference in terms of the types of ventilatory capacity. 439 cases with arterial $\mathrm{O}_{2}$ tension below 75 torr were chosen for the analysis. Figures without parenthesis indicate numbers of subjects and figures in the parenthesis represent percent prevalence. ${ }^{*} \mathrm{INDEX}$ : perent $\left(\mathrm{FEV}_{1} /\right.$ predicted VC), ${ }^{* * N O R M A L}$ : normal spirometry, ${ }^{* * *}$ RESTR : restrictive ventilatory impairment, ****COMBINED : combined ventilatory impairment, $* * * * *$ OBSTRUCT : obstructive ventilatory impairment.

\begin{tabular}{|c|c|c|c|c|c|c|c|}
\hline \multirow{2}{*}{$\begin{array}{l}\text { VENTILATORY } \\
\text { CARACITY }\end{array}$} & \multirow{2}{*}{$\begin{array}{l}\text { NO.OF } \\
\text { CASES }\end{array}$} & \multirow{2}{*}{\multicolumn{4}{|c|}{$\begin{array}{l}\text { ARTERIAL PO2 } \\
\text { DEIOW } 70\end{array}$}} & \multirow{2}{*}{\multicolumn{2}{|c|}{ below 50}} \\
\hline & & & & & & & \\
\hline $\begin{array}{l}\text { THAN } 35 \\
\text { NORHAL } \\
\text { RESTR } * * * \\
\text { COMBINED } \\
\text { OBSTRUCT } \\
\text { TOTAR }\end{array}$ & $\begin{array}{l}192 \\
85 \\
122 \\
157 \\
75 \\
439\end{array}$ & $\begin{array}{l}192 \\
85 \\
122 \\
157 \\
75 \\
439\end{array}$ & $\begin{array}{l}(100.0) \\
(100.0) \\
(100.0) \\
(100.0) \\
(100.0) \\
(100.0)\end{array}$ & $\begin{array}{l}130 \\
34 \\
84 \\
106 \\
49 \\
273\end{array}$ & $\begin{array}{l}(67.7) \\
(40.0) \\
(68.9) \\
(67.5) \\
(65.3) \\
(62.2)\end{array}$ & $\begin{array}{l}14 \\
2 \\
13 \\
9 \\
3 \\
27\end{array}$ & $\begin{array}{l}(0.3) \\
(2.4) \\
(10.7) \\
(5.7) \\
(4.0) \\
(6.2)\end{array}$ \\
\hline \multicolumn{8}{|l|}{ ARTERIAL PCOZ } \\
\hline $\begin{array}{l}\text { VENTILATORY } \\
\text { CAPACITY }\end{array}$ & $\begin{array}{l}\text { NO.OF } \\
\text { CASES }\end{array}$ & \multicolumn{6}{|c|}{$\begin{array}{l}\text { ARTERIAL PCOZ } \\
\begin{array}{|l|l|}36-45 & \text { below } 35\end{array}\end{array}$} \\
\hline $\begin{array}{l}\text { INDEX *LESS } \\
\text { THAN } 35 \\
\text { NORKAL } \\
\text { RESTR*** } \\
\text { COMBINED**** } \\
\text { OBSTRUCT******} \\
\text { TOTAL }\end{array}$ & $\begin{array}{l}192 \\
85 \\
122 \\
157 \\
75 \\
439\end{array}$ & $\begin{array}{l}61 \\
5 \\
11 \\
51 \\
7 \\
74\end{array}$ & $\begin{array}{l}(31.8) \\
(5.9) \\
(9.0) \\
(32.5) \\
(9.3) \\
(16.9)\end{array}$ & $\begin{array}{l}112 \\
67 \\
86 \\
95 \\
58 \\
306\end{array}$ & $\begin{array}{l}(58.3) \\
(78.8) \\
(70.5) \\
(60.5) \\
(77.3) \\
(69.7)\end{array}$ & $\begin{array}{l}19 \\
13 \\
25 \\
11 \\
10 \\
46\end{array}$ & $\begin{array}{l}(9.9) \\
(15.3) \\
(20.5) \\
(7.0) \\
(13.3) \\
(10.5)\end{array}$ \\
\hline
\end{tabular}

ALVEOLAR-ARTERIAL PO2 DIFFERENCE

\begin{tabular}{|c|c|c|c|c|c|c|c|c|c|c|c|}
\hline \multirow{2}{*}{$\begin{array}{l}\text { VENTELATORY } \\
\text { CAPACITX }\end{array}$} & \multirow{2}{*}{$\begin{array}{l}\text { No.OF } \\
\text { CASES }\end{array}$} & \multicolumn{10}{|c|}{$\mathrm{AaDO} 2$} \\
\hline & & \multicolumn{2}{|c|}{ below 10} & \multicolumn{2}{|c|}{$11-15$} & \multicolumn{2}{|c|}{$76-20$} & \multicolumn{2}{|c|}{$21-30$} & \multicolumn{2}{|c|}{ over 31} \\
\hline 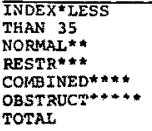 & $\begin{array}{l}192 \\
85 \\
122 \\
157 \\
75 \\
439\end{array}$ & $\begin{array}{l}5 \\
0 \\
0 \\
6 \\
0 \\
6\end{array}$ & $\begin{array}{l}(2.6) \\
(3.8) \\
(1.4)\end{array}$ & $\begin{array}{l}3 \\
1 \\
0 \\
2 \\
2 \\
4\end{array}$ & $\begin{array}{l}(1.6) \\
(1.2) \\
(1.3) \\
(1.3) \\
(0.9)\end{array}$ & $\begin{array}{l}5 \\
1 \\
2 \\
3 \\
1 \\
7\end{array}$ & $\begin{array}{l}(2.6) \\
(1.2) \\
(1.6) \\
(1.9) \\
(1.3) \\
(1.6)\end{array}$ & $\begin{array}{l}57 \\
23 \\
22 \\
52 \\
22 \\
119\end{array}$ & $\begin{array}{l}(29.7) \\
(27.1) \\
(18.6) \\
(33.1) \\
(29.3) \\
(27.1)\end{array}$ & $\begin{array}{l}122 \\
60 \\
98 \\
94 \\
51 \\
303\end{array}$ & $\begin{array}{l}(63.5) \\
(70.6) \\
(80.3) \\
(59.9) \\
(68.0) \\
(69.0)\end{array}$ \\
\hline
\end{tabular}

\section{5） $\mathrm{O}_{2}$ 吸入中の動脈血ガス：}

高度の呼吸障害があり，止むを得ず $\mathrm{O}_{2}$ 療法中 に動脈血ガス分析を行なつた症例が 146例あつ た. $\mathrm{O}_{2}$ 投与量が一定していなかつたので，㭘査成 績のらち，動脈血 $\mathrm{O}_{2}$ 分王にか九してはその詳細 を論ずることは出来ない。

動脈血 $\mathrm{CO}_{2}$ 分圧が36ないし45 T O R R の 正常䉕 囲内にあつたものは、観察症例の $31.5 \%$ に過ぎず， これは表 2 に示した呼吸不全例の空気呼吸中のこ れに対応する值 $51.6 \%$ に比し低かつた。この傾向 は疾患別に分類しても同様に認められた， $\mathrm{CO}_{2}$ 分 王が異常値を呈する症例数は45 T O R R 超它た ものでも，また，35T OR Rを下迴るものでる認 められたが，とくに肺気腫および喘息症例では $\mathrm{CO}_{2}$ の蓄積傾向を呈する症例が多く認められた，

\section{4. 考察ならひに結語}

著者は慢性呼吸不全の概念を本諭文の冒頭に述 べた通りに理解し，3129例（うち146例は酸素療 法中）の臨床例について実施した動脈血ガス分析 の成續を恰討した。
具体的な検討にあたつて動脈血ガス，例えば $\mathrm{O}_{2}$ 分玨にかんし，呼吸不全と判定すべき限界值を如 何倍定すべきかは重大な問題である．前述の定 義の理解の仕方としては，正常限界々のものを呼 吸不全の限界值とすることができないわけではな いしかし，その概念で規定している“そのため に生体が正常な機能を営み得なくなつた状態” が，果して正常限界をわずかにこえた条件でおこ るか否かは疑問とせざるを得ない，これまで発表 された論文でも，この限界值として，研究者はそれ ぞれ異なる值を設定していることが多い．この点 にかんし，しばしば引用されるのはCIBA GUEST SYMPOSIUMの報告 (1959) であるが，標題にも ".......chronic pulmonary emphysema and related conditions”とあり，“びまえ性閉塞性肺疾患の重 症度”として論が進められており，決して呼吸不 全全般について述べられているわけではない，著 者の得た成績からもわかるように呼吸不全の背景 となつている疾患は閉塞性肺疾患はその一部にす ぎず，肺線維化またはそれに関連をもつと推測さ 
れる一群の疾患がそれ以上に大きい部分を占めて いる。これらは閉塞性肺疾患とは病態の上でもい ささか異なる形をとり，後者がoverallの換気障害 が主体となり， $\mathrm{CO}_{2}$ 蓄積傾向を伴う呼吸不全を呈 するのに対して，前者では肺に括けるガス交換機

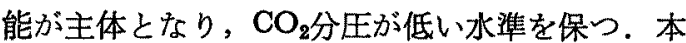
報告においては，極めて基本的な指標のみをとり あげて検討したが，これら症例では動脈血 $\mathrm{O}_{2}$ 分圧 の低下が著しい汪ど $\mathrm{CO}_{2}$ 分王が低い傾向があり， 呼吸機能の不均等分布の存在を示唆している。佐 藤 (1975) は動脈血・肺胞気 $N_{2}$ 分圷較差の 測定を 同時に行ない，動脈血低 $\mathrm{O}_{2}$ 症の原因としては肺に おける換気・血流比の不均等分布が重要であるこ とを証明した。

肺胞低換気を伴う呼吸不全と不均等分布を主体 とし，呼吸性アルカローシスを件う呼吸不全とは ある意味で両極端の病態であり，当然のことなが ら両者の中間的存在も少なくない。このように異 質の病熊を呈する呼吸不全例火，画一的閉塞性 肺疾患のための呼吸不全の基準を適用することは 妥当とは考支られない，著者は包括的に種々な病 態の呼吸不全に適用できる基準を理論的に導くこ とが可能とは考えないが，大方の合意に立脚した “申し合わせ”をつくるべく努力せ齐ばならない 之思う。

本論文において，著者は呼吸不全と診断するた めの $\mathrm{O}_{2}$ 分压の 基準を空気呼吸時に $75 \mathrm{TOR}$. して検討し，な拈参考のために70 T O R R 打よび 50 T O R Rを基準とした場合も仮定して瓶せ評価 した．呼吸性アルカローシスを伴ら場合には然ら ざる場合に較べて，同一の 動脈血 $\mathrm{O}_{2}$ 分圧に 対し ても $\mathrm{AaDo}_{2}$ を指標に評価したガス交換障害の程度 ははるかに著しい，呼吸不全の䛦断はその基本か らして動脈血ガスの值だけでなく，その生体機能 への影響を併せ勘案してなされねばならず，肺に 物ける機能障害の程度はあくまでも参考であるに すぎない，しかし多彩な病態を呈する呼吸不全の 診断の共通的基準を考光る場合には，動脈血 $\mathrm{O}_{2}$ な らびに $\mathrm{CO}_{2}$ 分圧の值に加えて $\mathrm{AaDo}_{2}$ を併せ考慮す ることは有意義であるらと考劣る、 $\mathrm{AaDo}_{2}$ を考兄

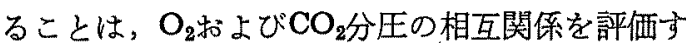
ることになり,一そら妥当な評価を可能ならしめ
ることにるなる。

著者は本研究の結論の一つとして，呼吸不全と して，診断されるべき動脈血検查所見として，

(1) $\mathrm{O}_{2}$ 分圧は75 T O R R以下， (2) $\mathrm{CO}_{2}$ 分王は 45 T O R R以上または35 T O R R以下，（3)参考と してAaDo 2 は2 $25 \mathrm{~T} \mathrm{OR} \mathrm{R}$ 以上を提案したい，上記

(1)特よび（2）の条件はいずれかをみたせばよい と考壳る。

\section{5. 要 約}

1）空気呼吸時江動脈血 $\mathrm{O}_{2}$ 分生 $75 \mathrm{~T} O R R$ 以 下を示した乎吸不全例1484例を含む臨床例，合計 3129例（うち146例は酸素療法中に検査を実施）飞 つき，行なつた動脈血ガス分析の成績を中心に報 告した。

2）疾患により，あるいは換気能力の障害の型 により，動脈血ガスの異常には無視し得ない相違 があり，呼吸不全の診断をいわゆる閉塞性肺疾患 の場合と同一の基準で行ならことは妥当でないと の結論に達した。

3）動脈血 $\mathrm{O}_{2}$ 分生が暴常に 低下している 症例 でも， $\mathrm{CO}_{2}$ 分圧は必ずしも高くはなく，それが45 T OR Rをこえたものと35T OR Rに達しないも のは互に同程度の発現率であつた。

4）呼吸性アルカローシスを伴う呼吸不全例て は，その成立の機序に肺に括けるガス交換機能の 不均等分布が重要な役割を果たしているるのと推 論された。

5）呼吸不全と判定する動脈血ガスを中心にし た呼吸病態生理学的立場からあらためて検討し， 新しい“申し合わせ”をつくることが必要である ことを述べ，著者の考劣一例として述べた．

\section{文献}

1) Terminology, definitions and classification of chronic pulmonary emphysema and related conditions. A report of the conditions of a CIBA guest symposium, Thorax 14: 286 299, 1959. -2）笹本浩，横山哲朗：肺不全々呼吸不全，呼吸々

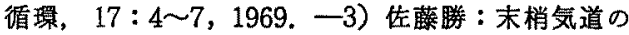
病態飞関する臨床的研究 (1) 肺胞気・動脈血ガ ス 分王較差の臨床的意義，日本胸部疾患学会誌揭截 予定. 一4) 横山哲朗：換気・血流比不均等分布飞 かん寸る研究 (2) 動脈血・肺胞気 $\mathbf{N}_{2}$ 分压について の臨床的観察, 日本胸部疾患学会誌, $7: 130 \sim 136$, 1969 - -5) 横山哲朗：䏢の末梢湎域におりる呼 吸障害，日本胸部疾患学会誌，12：501 514, 1974 